IZA DP No. 7887

Unionization and Productivity: Evidence from Charter Schools

Cassandra M. D. Hart

Aaron J. Sojourner

January 2014 


\title{
Unionization and Productivity: Evidence from Charter Schools
}

\author{
Cassandra M. D. Hart \\ University of California, Davis \\ Aaron J. Sojourner \\ University of Minnesota \\ and IZA
}

\section{Discussion Paper No. 7887 \\ January 2014}

IZA
P.O. Box 7240
53072 Bonn
Germany

Phone: +49-228-3894-0

Fax: +49-228-3894-180

E-mail: iza@iza.org

Any opinions expressed here are those of the author(s) and not those of IZA. Research published in this series may include views on policy, but the institute itself takes no institutional policy positions. The IZA research network is committed to the IZA Guiding Principles of Research Integrity.

The Institute for the Study of Labor (IZA) in Bonn is a local and virtual international research center and a place of communication between science, politics and business. IZA is an independent nonprofit organization supported by Deutsche Post Foundation. The center is associated with the University of Bonn and offers a stimulating research environment through its international network, workshops and conferences, data service, project support, research visits and doctoral program. IZA engages in (i) original and internationally competitive research in all fields of labor economics, (ii) development of policy concepts, and (iii) dissemination of research results and concepts to the interested public.

IZA Discussion Papers often represent preliminary work and are circulated to encourage discussion. Citation of such a paper should account for its provisional character. A revised version may be available directly from the author. 
IZA Discussion Paper No. 7887

January 2014

\section{ABSTRACT}

\section{Unionization and Productivity: Evidence from Charter Schools}

This paper studies the relationship between teacher unionization and student achievement. Generally stable patterns of teacher unionization since the 1970 s have historically presented challenges in measuring the effects of unionization on educational production. However, the blossoming of the charter school sector in recent decades provides fertile ground for study because while most charters are non-union, teachers at some charters have unionized. Using a generalized difference-in-difference approach combining California union certification data with student achievement data from 2003-2012, we find that, aside from a one-year dip in achievement associated with the unionization process itself, unionization does not affect student achievement.

JEL Classification: $\quad$ I21, J5, J45, J24, H75, D24

Keywords: teacher, labor union, student achievement, charter school, education, labor productivity

Corresponding author:

Aaron J. Sojourner

University of Minnesota

Carlson School of Management

321 19th Ave S

Minneapolis, MN 55409

USA

E-mail: asojourn@umn.edu 
Student learning matters greatly to our society’s health and depends crucially on teachers’ productivity, which varies greatly. Based on conservative estimates from recent work (Chetty, Friedman, Hilger, Saez, Schanzenbach, \& Yagan; Hanushek, 2010), a one standard deviation improvement in teacher productivity per teacher per year - equivalent to producing a 0.2 standard deviation increase in student achievement - generates about $\$ 200,000$ in net present value social returns by raising students’ future private earnings and reducing their demand for public expenditures. Given the importance of variation in teacher productivity for long-term economic potential, policymakers have a keen interest in exploring the conditions that foster or undermine teacher productivity. In recent years, unionization has attracted great attention as a candidate factor that may affect teacher productivity. ${ }^{1}$

The effect of unions on average labor productivity in organizations generally (Freeman \& Medoff, 1984) and in schools specifically (Eberts, 1987; Hoxby, 1996) is theoretically ambiguous. First, consider how changes in effort and job design might affect productivity, holding the set of workers and managers fixed. On the positive side, increased commitment between the worker and firm and greater training opportunities may raise productivity (Acemoglu \& Pischke, 1998). On the negative side, unions may advocate for restrictive work rules (such as strict limits on on-site workday length or division of tasks between job categories) and blunt incentives (such as seniority-based personnel rules and resistance to performance pay), which may lower effort and productivity (Moe, 2011). Second, consider changes in resource allocation. Unions might shift the mix of inputs and raise school budgets in productivity-enhancing ways by increasing teachers' ability to bring their superior expertise in educational production to bear on policymaking, or they might produce shifts in the allocation of resources in ways that enhance teacher satisfaction at the expense of students (Rose \& Sonstelie, 2010). Third, unionization may affect who works at an organization in complex ways, leading unionized schools to have different sets of teachers and managers than nonunion schools 
(Pettengill, 1979; Freeman \& Kleiner, 1990; Card, 1996). Which of these channels dominates remains an important, unsettled empirical question in organizations generally and in schools particularly (Eberts, 2007; Lovenheim, 2009).

Credibly identifying union effects on student achievement is difficult. Unionized schools may differ systematically from nonunion schools in many ways besides unionization. For instance, if urban schools are more likely to unionize and to serve more-disadvantaged, lower-achieving students than non-urban schools, unionized schools will have lower average student achievement. However, we would not want to interpret this negative association as causal. To help guard against such problems, we condition on a rich set of observable student and school characteristics at the schoolgrade-year level. This leaves the possibility of systematic differences between unionized and nonunion schools in unobservable determinants of achievement.

To address this possibility, we avoid making comparisons across schools. Instead, we use panel data to study only how changes over time in unionization status are associated with changes in student achievement within school-grade-subject. This generalized difference-in-difference design conditions out any stable, additive differences in unobservable achievement determinants between school-grade-subjects. The remaining threat to identification is the possibility of changes in timevarying unobservables correlated with changes in unionization status. We use the multiple years of pre-unionization data to address this concern. If soon-to-unionize schools were experiencing differential achievement trends compared to other schools, this test would detect a spurious preunionization "effect" of future unionization, which could not be causal and would be evidence of selection into unionization on unobservable trends (Lovenheim, 2009; Sojourner, Mykerezi, \& West, forthcoming). We see no such evidence. The remaining threat is a possible difference in changes in unobservables that starts coincident with unionization, but not before. Such a change would be confounded with unionization. 
Our analysis focuses on unionization in California charter schools. This setting offers several useful features that generate the study's main contributions. First, charters provide a unique degree of within-state variation in unionization status. To the extent that state law allows, charter-school teachers have rights to unionize and, in many cases, they have done so. A 2009-10 nationwide survey found that 604 charter schools nationwide had collective bargaining agreements with their teachers' union, constituting 12.3\% of charter schools (National Alliance for Public Charter Schools, 2011). California, like many other states, allows charter unionization when a majority of a school's teachers express support for collective bargaining. Once this occurs, it sets off the formal collective bargaining process and shifts the employment relationship from unilateral to bilateral governance. In contrast, other states bind charter schools to whatever collective bargaining agreements exist in the regular school district in which they are located, and seven states bar teacher collective bargaining (Freeman \& Han, 2012).

Second, charter schools are a good context for observing potentially large changes induced by unionization. Though publicly-funded, charter schools are granted more operational flexibility than traditional public schools. In particular, unlike traditional public schools, they tend to operate outside existing collective bargaining agreements (Guarino, 2003). ${ }^{2}$ Because a shift to collective bargaining constitutes a major departure from the default position of managerial flexibility, unionization may induce substantial changes in organizational practice that would affect teacher productivity and student achievement.

Third, California has been at the forefront of the explosive proliferation in charter schools nationwide since the first charter schools were established in the early 1990s. As of 2010-11, there were 5200 schools in operation nationwide, educating roughly $4 \%$ of the nation's K-12 public student population (National Center for Education Statistics, 2012). Over 900 of these were in California. The Golden State boasts over 60\% more charter schools than Texas, the state with the second-most charters (National Center for Education Statistics, 2012). 
Fourth, California provides a relatively large number of schools where teachers switched unionization status within the period covered by achievement data, permitting analysis of unionization holding the school fixed. Since 1999, California has allowed teachers within each charter school to unionize by showing majority support, either through secret-ballot election or cardcheck (California Public Employment Relations Board, 2006). ${ }^{3}$ According to the Public Employment Relations Board (PERB), forty-two California charter schools switched unionization status at various points during the study period. These 42 schools include 226,174 tested student-years. This is far more than is available in other states. ${ }^{4}$ In addition, the large number of California charter schools that did not switch unionization status benefits our study by providing a sizeable comparison group, improving our estimates’ precision.

Fifth, this sample also allows us to harness rich measures of student achievement over a wide group of students over a long period. Specifically, we use average student achievement by schoolgrade-subject on California state tests for every school year from 2002-03 through 2011-12. Because different states mandate different achievement tests, obtaining consistent measures is possible only by looking within a single state. Prior district-level, multi-state studies usually rely on dropout rates as the outcome (Hoxby, 1996; Lovenheim, 2009). These are noisy, influenced by variation in the local economy, based on a binary underlying measure, and capture variation only at the lowest levels of achievement (Heckman \& LaFontaine, 2010). Another candidate outcome, nationallyadministered achievement tests such as the National Assessment of Educational Progress, are taken by only a small sample of schools in each state level and are not representative of schools or districts.

Finally, the recency of the data used in this study is one of its primary contributions. Most changes in state collective-bargaining laws for teachers occurred before 1980. Teacher unionization patterns have been quite stable over the decades since then (Lovenheim, 2009; Frandsen, 2011). This stability has left researchers reliant on either (a) cross-sectional comparisons subject to concern about stable unobserved differences between union and nonunion districts that may be correlated with 
unionization or (b) panel methods that condition out fixed unobservable differences but applied to changes in unionization that took place decades ago. In one of the first studies on the effects of teachers unions on student achievement, Eberts (1987) drew on a national cross-sectional survey to compare teacher productivity with respect to student achievement in districts with and without collective-bargaining agreements. He found a positive association between unionization and productivity. A more recent cross-sectional study found negative relationships between union strength and student achievement among unionized districts in California (Rose \& Sonstelie, 2010). Other work has utilized panel designs. Using changes in districts' unionization status instrumented by changes in states’ teacher collective bargaining laws between 1972 and 1992, Hoxby (1996) found that unionization lowered student achievement, measured by high-school dropout rates. Lovenheim (2009) uses a similar design to study unionization effects on dropout rates in a panel of school districts in three states focusing on the same period. He finds that teacher unionization did not affect dropout rates and attributes the difference in results to superior measurement of unionization. Thus, the empirical literature, as well as the theoretical, is ambiguous.

Examining unionization in recent years is important because substantial changes in nonteaching job opportunities for women have made teacher labor markets—and, therefore, the probable effects of policies that influence teachers' work incentives—-potentially different from decades ago. There is strong evidence that these trends in the labor market have affected the productivity distribution of potential teachers (Corcoran, Evans, \& Schwab, 2003).

While our design gives the analysis credible, internally valid estimates of union effects in charter schools, differences between charter schools and traditional public schools in managerial flexibility, funding determinants, and competition may limit the external validity somewhat. We return to these issues in the concluding discussion. 


\section{Data and Model}

The primary treatment variable of interest is a binary variable indicating whether teachers in school $s$ are unionized in a given school-year $t\left(U_{s t}\right)$. We observe the date that a school's teachers unionize based on the California PERB bargaining-unit certification archival records. PERB has data for all schools that formally underwent a unionization process. ${ }^{5}$ In some cases, schools retained bargaining units that were in place when the schools converted from traditional to charter schools. To capture this, we use the unionization status variable from a 2009 survey of all charters operating nationwide (National Alliance of Public Charter Schools, 2012). Charter schools that reported being unionized in this survey but which were not certified by PERB are assumed to have been alwaysunionized. This group disproportionately comprises charters that converted from traditional schools, rather than starting up as an entirely new school.

Across the sample period as a whole, each charter school falls into exactly one of three categories: always union, never union, or unionizer. We also refer to unionizers as switchers; no schools de-unionize. Switchers are those observed as unionizing through PERB records. For each switcher in a given year, the school is either not-yet-union or now-union. Table 1 describes the number of charter schools with tested students that fall into each of these four categories each year. ${ }^{6}$ The number of California charter schools (with tested students) expanded quickly over the period, nearly tripling from 330 to 935 schools between the 2002-03 and 2011-12 academic years. Given entry and exit into existence and the rules regarding testing, this includes 1,126 unique schools with publicly-reported achievement data. Of these, 42 schools switched from non-union to union between 2003 and 2012, providing both pre- and post-unionization achievement data, and allowing the basis for identification. Of the other schools, 99 were always unionized and 985 never unionized. The right panel of Table 1 describes the corresponding numbers of tested students.

Switches into unionization occurred at a stable pace over the period, which has both disadvantages and advantages from a research design perspective. On the negative side, we do not 
have legal changes that shock the unionization process, which others have used to help eliminate omitted-variables bias (Hoxby, 1996; Lovenheim, 2009). ${ }^{7}$ On the positive side, the variation in unionization timing ensures that unionization effects are not confounded with simultaneous changes or time effects in the environment that might affect all schools in the state.

Our primary outcome of interest is student achievement $\left(Y_{\text {sgbt }}\right)$, which is measured as the school-grade-subject-year average on California's state standardized tests for each charter school in each school year from spring 2003 to spring 2012 for math, reading, science, and history in all available tested grades. This is available for a given school-grade-subject whenever at least 11 students were tested. California tests students in grades two through eleven using the California Standards Tests (California Department of Education, 2012). The schedule of mandated testing by grade-subject is in Appendix Table 1. We convert each school-grade-subject-year average score into a z-scores using the corresponding statewide individual achievement norms in order to facilitate pooling and render effects interpretable in standard deviation $(\sigma)$ units. Because our theory of the relation between unionization and productivity is not grade- or subject-specific, our analysis pools all available information to maximize precision.

Average school-grade-subject achievement is also influenced by observable average student characteristics, like student affluence, that might also be correlated with unionization. To deal with this, we control for a rich set of demographic characteristics of school student-body composition drawn from the California Department of Education’s Academic Performance Index records, including fraction of students who are English-language learners, African-American, Asian, American Indian, Filipino, Hispanic/Latino, eligible for reduced-price lunch, whose highest-educated parent is a high school graduate, has some college, is a college graduate, has an advanced degree, and fraction with parental education observed. ${ }^{8}$ The age of the charter school may also be associated with both average achievement and schools' unionization status. We include two indicators for age of the 
charter school: $1(6-10 \text { years as charter })_{s t}$ and $1(11+\text { years as charter })_{s t}$ Together, all these variables constitute the time-varying conditioning variables, $X_{\text {st }}$.

We characterize the relationship between student achievement and teacher unionization with a generalized difference-in-difference approach. At base, the idea is to compare the change in achievement levels that occurs as unionization status changes (the difference of average postunionization achievement and average pre-unionization achievement) in schools that unionize to achievement changes over the same period in schools where unionization status did not change. Unobservables are partitioned additively into three components: the average for each school-gradesubject $\left(\gamma_{s g b}\right)$, the average for each year $\left(\delta_{t}\right)$, and a residual $\left(\varepsilon_{s g t b}\right)$ :

$$
\text { (1) } Y_{s g b t}=\beta U_{s t}+\alpha X_{s t}+\gamma_{s g b}+\delta_{t}+\varepsilon_{s g b t}
$$

The model focuses on variation in achievement within school-grade-subject over time that is correlated with changes in school unionization status. The effect of unionization on student achievement is measured by $\beta$. As in Lovenheim (2009) and Sojourner, Mykerezi, \& West (forthcoming), identification requires that trends in unobserved residual influences are not correlated with changes in unionization conditional on other observables: $E\left[\varepsilon_{s g b t} \mid U_{s t}, X_{s t}, 1_{s g b}, 1_{t}\right]=0$. In all cases, we will allow for heteroskedasticity and within-school correlation of errors across students, subjects, grades, and years by estimating cluster-robust standard errors.

The availability of multiple years of data prior to unionization allows for testing of this crucial identifying condition and the development of evidence on how changes in achievement might drive unionization, rather than the other way around. By representing $U$ as a full set of leads and lags capturing how far the observed year is from the school's switch into unionization, we can look for systematic differences in unobservable achievement determinants leading up to unionization (selection), as well as subsequent to unionization (effects). For instance, if schools that will unionize in two years are more likely to be experiencing falling achievement than otherwise similar schools, 
then this would suggest some kind of negative selection into unionization and that care is warranted in interpreting post-unionization differences as simply “effects” of unionization. Deteriorating management or teaching quality may both drive falling achievement and increase teachers’ desire to unionize. On one hand, arbitrary or ineffective management may produce bad results for students and a strong resolve by teachers to unionize in order to assert control over an institution they value and to build power to do their jobs more effectively. ${ }^{9}$ On the other hand, ineffective teachers may also produce bad results for students and seek stronger job protection through unionization. ${ }^{10}$

\section{Results}

Bivariate analysis: Table 2 gives descriptive statistics in terms of student performance and student body characteristics of the charter schools included in this study for all charters (Column 1). Never-Unionized charters (Column 3) have somewhat more advantaged student bodies along several dimensions compared to their Switcher (Column 2) or Always-Unionized (Column 4) counterparts. They have lower shares of English Learners than the Ever-Unionized schools, and they have slightly lower shares of students eligible for subsidized meals. They also have the lowest share of students with parents who did not finish high school, although they have a lower share of students whose parents finished graduate school than do Always-Unionized charters.

Despite their less advantaged student bodies, however, unionized charters - both those that are always unionized and those that switch from non-union to unionized-outperform their neverunionized counterparts on average. Pooling data across all subjects and years, Table 2 shows that Never-Unionized charters have lower average achievement. Figure 1 shows that this reflects a consistent trend: Never-unionized charters are the lowest-performing group across all years. The gap is becoming less pronounced over time, however, due to a decline in the always-unionized trend.

There are two reasons that the relative achievement of unionized schools may exceed that of their non-unionized counterparts. First, it may be that schools that opt into unionization are schools that are relatively high-performing prior to unionization and that this advantage persists after the 
unionization process, even if there is no causal change attributable to unionization. Second, it may be that unionization itself boosts school (and therefore student) performance.

Regression analysis: We explore these relationships further with regression analysis. Table 3 reports results from a series of progressively richer models. Column 1 confirms the pooled crosssectional relationship reported in Table 2; before any controls are added, a simple indicator of whether a school-year is post-unionization is significantly associated with a 0.258 standard deviation increase in student achievement. The positive, significant association between unionization and student achievement remains as we add year fixed effects and subject-grade fixed effects (Column 2). The association falls to 0.135 but grows more precise and remains significant when we add controls for observable demographics of the student body and age of the charter school (Column 3).

The positive association between unionization and achievement disappears, however, once we hold the school constant and identify only off of the change of unionization status within schools. Column 4 adds school fixed-effects; the coefficient on Post-unionization becomes non-significant and drops to near-zero in magnitude. ${ }^{11}$ This only conditions out average unobservables school-wide and for each subject-grade across schools. To construct a better counter-factual, we substitute schoolgrade-subject fixed effects in place of the school- and subject-grade fixed effects (Column 5). This analysis conditions out average unobservables for each school-grade-subject and studies how changes in achievement within this unit of observation are associated with changes in unionization. We find similar results. We consider this our preferred specification because it uses all available information from the charter-sector, includes the richest controls, and is a straightforward differencein-difference estimator of the effect of unionization on achievement. The point estimate implies that unionization raised average achievement by 0.017 standard deviations, though this is not statistically distinguishable from a null effect. The 95\% confidence interval is $(-0.055,0.090)$.

In the final specification in Table 3, we check for time trends in unobservable achievement determinants correlated with future unionization (Column 6). Specifically, we add an indicator for 
whether each school-year is two or more years prior to unionization. The omitted year is that immediately prior to unionization. Thus, the coefficients on both the Post-unionization and the $2+$ years pre-unionization variables are interpreted in relation to the last year that schools are observed as non-union. The comparison is made to changes over the same time period experienced by Never-Unionizing schools. Both coefficients are non-significant and modest in magnitude, suggesting that unionization has little effect on achievement and that there is not strong selection into unionization. If the soon-to-unionize schools were experiencing differential trends leading into unionization than other schools, the 2+years pre-unionization coefficient would be non-zero.

Figure 2 displays results from a more flexible estimation strategy that replaces the two preand post-unionization dummies with a large set of leads and lags; estimates are reported in the Appendix Table A.2. We substitute dummies indicating the number of years until or after unionization, leaving the last pre-unionization year as the omitted category. Observations from five and more years pre-unionization are collapsed into one category, as are observations six and more years post-unionization. The bars represent the $95 \%$ confidence interval around the point estimates. Student achievement is significantly higher in the third, fifth, and six-plus post-unionization years than in the (omitted) last pre-union year. However, the pre-unionization trends suggest that these improvements are less due to novel gains than due to the fact that the years near unionization are marked by particularly low achievement for unionizing schools. In particular, average achievement in the lead year (the omitted year) is significantly lower than achievement in the second lead year, and there are marginally significant achievement differences between the omitted year and the third $(\mathrm{p}<.11)$ and fourth $(\mathrm{p}<.10)$ lead years. Indeed, if the second lead year is used as the omitted year, none of the other years besides the first lead year are significantly different. This suggests that the year before unionization is finalized may be a uniquely disruptive one. There seems to be a dip in student performance around the same time as unionization but student performance rebounds within a few years to levels comparable to performance levels before the drive for unionization occurred. 
Robustness: Taken together, Figure 2 and Table 3 suggest that there are no clear postunionization trends, but also no significant pre-unionization trends, in achievement. Because the results are fundamentally similar across both specifications, we return to the baseline difference-indifference specification for robustness tests (as in Table 3, Column 5), rather than using the full set of lead and lag indicators depicted in Figure 2. We conduct several checks to determine whether the results hold up under different approaches.

An initial concern may be that the sample we use in our main results—-the full set of charter schools, in years they are operating as charters-is either too restrictive or too inclusive. Therefore, we re-estimated the model presented in Table 3, Column 5 using different samples to determine whether our main results are sensitive to sample selection. For instance, one may be concerned about the inclusion of the Always-Unionized schools, because the model is identified off of differences in time trends and Figure 1 shows that Always-Unionized schools have a downward-sloping trend that is distinct from the other types of schools. Excluding Always-Unionized schools from the sample yields estimates (Table 4, Column 2) that are almost identical to the main results (reproduced for ease of comparison in Table 4, Column 1). Furthermore, one may prefer to identify exclusively off of the differences in unionization timing among the switchers. In this specification (Column 3), unionization is associated with a decline in achievement. Further tests (available on request) replicating the specification in Column 6 indicate that this is driven by negative selection into unionization; the coefficient on the $2+$ years pre-unionization variable is significant and positive ( $b=0.130$, se=0.036), while the Post-unionization variable is not significantly different than 0 . Seeking to increase precision as much as possible, we next expand our sample to include traditional public schools (TPS; Column 4); this has little effect on the results.

A second concern may be that there is mis-measurement in school unionization status. In particular, 12 of our Switcher schools are Conversion schools, as are many of the schools that are classified as Always-Union for whom we did not observe PERB paperwork. We may be worried that 
these 12 schools are simply formalizing a union that has always existed in practice, and that they are mis-categorized as Switchers. We therefore run our results limiting the sample only to start-up (nonConversion) charters (Column 5); results are consistent with the main sample.

A third set of tests explores the sensitivity of our outcomes to the metric used to measure student achievement. In addition to reporting average scale scores for each school-grade, the California Department of Education reports the share of students who fall into each of five achievement categories for each subject test in the California Standards Tests: Advanced, Proficient, Basic, Below Basic, and Far Below Basic. We re-estimate the models from Table 3, Column 5 using three new outcome variables: percent Advanced (Table 5, Column 1), percent Proficient or higher (Column 2), and percent Basic or higher (Column 3). The story is largely similar when we use these different ways of measuring achievement: Most coefficients remain non-significant and modest.

A fourth set of tests explored the sensitivity of the results to the use of different tests. Specifically, we wanted to explore whether we observe heterogeneous effects on the two subjects most heavily tested by the California Standards Tests: math and reading (known in California standardized testing as English Language Arts [ELA]). Table 6 reports results based on each type of achievement test using specifications analogous to Column 5 of Table 3 but eliminating the subject components of the fixed effects. The results show that while the magnitude of the coefficient for math is somewhat larger than for ELA, neither is significantly different than 0 .

We likewise tested the robustness of our results to using the (year-standardized) Academic Performance Index (API) score for each school. The API is the primary metric used for the state's school accountability regime. The API aggregates information for each school from all of the California Standards Tests that constitute our primary outcomes of interest, as well as modified assessments for students with disabilities and the California High School Exit Exam. Because the API is calculated at a school level, these analyses used school (rather than school-grade or school- 
subject-grade) fixed effects. Again, our results, reported in Table 6, Panel B, are substantively similar to our main results using the pooled, subject-specific California Standards Tests.

A final set of analyses probes whether unionization has effects on other charter variables, including log enrollment, composition, or school closure. These analyses find little evidence that unionization affects school enrollment or demographic composition (see Appendix Table A.3). Hazard analyses predicting school closure vary somewhat with the sample (Appendix Table A.4); however, in no case does unionization positively and significantly predict closure. ${ }^{12}$

\section{Conclusion}

We find little evidence that unionization affects student achievement in charter schools. While there is some evidence that student performance dips around the time of unionization, it seems to rebound to previous levels within a few years. These findings are robust to estimation using different specifications, different samples, and different outcomes.

There are several possible explanations for this pattern of findings. First, the unionization process itself may temporarily distract teachers, managers or students from achievement. Second, a drop in management quality may drive down achievement and drive teachers to unionize. Through organization, teachers may be able to increase control over the organization, circumvent management mistakes, and get achievement back on track. Third, teachers may feel a drive to unionize because of some temporary fluctuation within the school that also temporarily reduces test scores. This problem may then dissipate of its own accord, leaving teachers unionized and scores back on track. One story that is inconsistent with the pattern is that deteriorating teacher performance drives unionization in order to increase job security. In that case, given increased protection for worsening teachers, we would expect no post-unionization rebound in student achievement.

There are caveats to these findings. First, there is evidence that union effects on productivity are more negative in firms operating in less competitive product markets (Hirsch \& Addison, 1986; Sojourner, Town, Grabowski, Chen, \& Frandsen, 2013). ${ }^{13}$ Because traditional public schools are 
universally available, charters always have traditional public schools as competitors, whereas a traditional public school district may or may not have competition from charters nearby. Therefore, charters may face systematically more competitive markets than traditional schools and the effects of teachers unions may accordingly be smaller for charters.

Second, this study cannot provide direct evidence about the effects of unionization on costs and, hence, on productivity per unit labor cost. Past research has found that teachers generally earn higher compensation in districts where unions are stronger (Brunner \& Squires, 2013; Rose \& Sonstelie, 2010). Ideally, we would like to test whether teachers similarly capture compensation gains when their charter schools unionize. Unfortunately, California does not collect school-level data on revenues, expenditures, or compensation (California Department of Education, Personal Communication, 8/28/2013). However, the charter school funding process suggests that unionization in charter schools is unlikely to affect that school's per student funding. Unlike teachers in traditional public school districts in other states, if teachers in a California charter school unionize, they cannot raise school revenues by lobbying for a local property tax increase, and California state funds are distributed according to rules that charter unions are unlikely to be able to affect (Taylor, 2012). Unionization may affect the share of school expenditures spent on teachers but, evidently, not in a way that is detrimental to student achievement. Nonetheless, the effects of unionization on teacher compensation, as well as on related teacher labor market outcomes like retention and mobility, is an important area for future study.

Finally, the generalizability of our results to traditional public schools may be limited because collective bargaining agreements in charter schools are often less restrictive than in traditional public schools. For instance, teachers in Green Dot charter schools are unionized, but they do not have tenure, and transfers between branches of the school are not governed by seniority rights (Moss, 2010; Moe, 2011). Likewise, they lack agreements on work conditions, like the number of hours per day they can be expected to work, that are subject to labor agreements in California's 
traditional public schools. Charter school teachers may be more open to unconventional union strategies, such as employee-empowerment, rather than the more conventional job-control strategy. Employee-empowerment strategies put greater emphasis on increasing investment in worker skills and voice in decisions rather than focusing on language that tightly defines the rights inherent in a job. ${ }^{14}$ And as noted above, there are differences in the funding structures of charters and traditional public schools that may render the effects of unions on student achievement in the two sectors slightly different. The source of these cross-sector differences is an area for future work. Because unions in charter schools may operate differently than those in traditional schools, our results may generalize to the traditional sector imperfectly.

Despite these limitations, this study makes important contributions. It both extends exploration of the effects of unionization on educational achievement to recent years, and provides the first estimates of the effects of unionization in the increasingly-important charter school sector. Our finding that teacher unionization in charter schools appears to have little effect beyond a oneyear dip will be of interest to voters, parents and policymakers seeking to understand the impact of potential changes to public sector labor relations laws, to school managers considering labor relations strategy, and to teachers debating whether to push for unionization. 


\section{Bibliography}

Acemoglu, Daron and Jorn-Steffen Pischke. 1998. Why Do Firms Train? Theory and Evidence. Quarterly Journal of Economics, 113(1), 79-119.

Blume, Howard. 2012. Charter school group's chief blamed for 2010 cheating scandal. Los Angeles Times. (Aug 17, 2012). Accessed 9/4/2013 at: http://articles.latimes.com/2012/aug/17/local/la-me-crescendo-20120818

Brunner, Eric, \& Tim Squires. 2013. “The Bargaining Power of Teachers' Unions and the Allocation of School Resources. Journal of Urban Economics, 76, 15-27.

Budd, John W. 2004. Employment with a Human Face: Balancing Efficiency, Equity, and Voice. Ithaca, N.Y.: Cornell University Press.

California Department of Education. 2012. About 2012 STAR. Retrieved from http://star.cde.ca.gov/star2012/aboutSTAR.aspx

California Department of Education. 2013. 2013-14 Student Testing Dates. Retrieved August 14, 2013, from www.cde.ca.gov/ta/tg/sa/assess1314testdates.asp

California Public Employment Relations Board. 2006. Filing a Request for Recognition under the Educational Employment Relations Act. Retrieved August 23, 2013, from Public Employment Relations Board: http://www.perb.ca.gov/forms_pubs/pdfs/PERB2190.pdf

Card, David. 1996. The Effect of Unions on the Structure of Wages: A Longitudinal Analysis. Econometrica, 64(4), 957-979.

Chetty, Raj, John N. Friedman, Nathaniel Hilger, Emmanuel Saez, Diane Whitmore Schanzenbach, and Danny Yagan. 2011. How Does Your Kindergarten Classroom Affect Your Earnings? Quarterly Journal of Economics, 126(4), 1593.

Chubb, John E., and Terry Moe. 1990. Politics, Markets, and America's Schools. Washington, D.C.: The Brookings Institution.

Corcoran, Sean P., William M. Evans, and Robert M. Schwab. 2003. Women, the Labor Market, and the Declining Relative Quality of Teachers. Journal of Policy Analysis and Management, 23(3): 449-470.

Eberts, Randall. 1987. Teacher Unions and the Productivity of Public Schools. Industrial \& Labor Relations Review, 40(3), 354-363.

Eberts, Randall. 2007. Teachers Unions and Student Performance: Help or Hinderance? The Future of Children, 17(1), 175-200. 
Frandsen, Brigham. 2011. The Effects of Public-Sector Collective Bargaining Rights. Unpublished.

Freeman, Richard B., \& Eunice Han. 2012. The War Against Public Sector Collective Bargaining in the US. Journal of Industrial Relations, 54(3), 386-408.

Freeman, Richard B., \& Morris M. Kleiner. 1990. Employer Behavior in the Face of Union Organizing Drives. Industrial and Labor Relations Review, 43(4), 351-365.

Freeman, Richard B., and James L. Medoff. 1984. What Do Unions Do? New York, NY: Basic Books.

Guarino, Cassandra. 2003. Staffing in Charter and Conventional Public Schools. In R. Zimmer, R. Buddin, D. Chau, G. Daley, B. Gill, C. Guarino, et al., Charter School Operations and Performance: Evidence from California (pp. 143-160). Santa Monica, Cal.: RAND Corporation.

Hanushek, Eric. 2010. The Economic Value of Higher Teacher Quality. Economics of Education Review, 30(3), 466-479.

Hart, Gary K., and Sue Burr. 1996. The Story of California's Charter School Legislation. The Phi Delta Kappan, 78(1), 37-40.

Heckman, James J. and Paul A. LaFontaine. 2010. The American High School Graduation Rate: Trends and Levels. Review of Economics and Statistics, 92(2), 244-262.

Hirsch, Barry T., and John T. Addison. 1986. The Economic Analysis of Unions: New Approaches and Evidence. London, U.K.: Allen \& Unwin.

Hirsch, Barry T., and David A. Macpherson. 2013. Union Membership and Coverage Database from the CPS. Retrieved 6 12, 2013, from unionstats.com: http://unionstats.com/

Hoxby, Caroline Minter. 1996. How Teachers' Unions Affect Education Production. Quarterly Journal of Economics, 111(3), 671-718.

Hoxby, Caroline Minter. 2000. Does Competition among Public Schools Benefit Students and Taxpayers? American Economic Review, 90(5), 1209-1238.

Lovenheim, Michael. 2009. The Effect of Teachers' Unions on Education Production: Evidence from Union Election Certifications in Three Midwestern States. Journal of Labor Economics, 27(4), 525-587.

Moe, Terry. 2011. Special Interest: Teachers Unions and America's Public Schools. Washington, D.C.: Brookings Institution. 
Moss, James R. 2010. Collective Bargaining in California Charter Schools: Cooperation or Conflict? University of Southern California dissertation.

National Alliance for Public Charter Schools. 2011. Unionized Charter Schools: Data from 2009-10. Washington, D.C.: National Alliance for Public Charter Schools.

National Alliance of Public Charter Schools. 2012. The Public Charter Schools Dashboard. Retrieved June 2012, from http://dashboard.publiccharters.org/dashboard/home

National Center for Education Statistics (2012). Common Core of Data. Washington, DC: United States Department of Education. Retrieved August 12, 2013, from Public Elementary/Secondary School Universe Survey, provisional version 2a: http://nces.ed.gov/pubs2012/pesschools10/tables/table_02.asp and http://nces.ed.gov/pubs2012/pesschools10/tables/table_03.asp

Pettengill, John S. 1979. Labour Unions and the Wage Structure: A General Equilibrium Approach. Journal of Political Economy, 46(4), 675-693.

Rose, Heather, \& Sonstelie, Jon. 2010. School Board Politics, School District Size, and the Bargaining Power of Teachers' Unions. Journal of Urban Economics, 67, 438-450.

Sojourner, Aaron J. 2013. Do Unions Promote Members' Electoral Office Holding? Industrial \& Labor Relations Review, 66(2), 467-486.

Sojourner, Aaron J., Elton Myzereki, and Kristine West (Forthcoming.) Teacher Pay Reform and Productivity: Panel Data Evidence from Adoptions of Q-Comp in Minnesota. Journal of Human Resources.

Sojourner, Aaron J., Robert J. Town, David C. Grabowski, Michelle M. Chen, and Brigham Frandsen. 2013. Impacts of Unionization on Quality and Productivity: Regression Discontinuity Evidence from Nursing Homes. University of Minnesota manuscript.

Taylor, Mac. 2012. Comparing funding for charter schools and their school district peers. Sacramento, CA: California Legislative Analytst's Office.

Tiebout, Charles M. 1956. A Pure Theory of Local Expenditures. Journal of Political Economy, 64(5), 416-424.

Walker, Tim. 2013. In Charters, Unions See More Opportunity. NEA Today, (Summer 2013). pp. 58-63.

Wells, Amy Stuart. 1998. Charter School Reform in California: Does It Meet Expectations? The Phi Delta Kappan, 80(4), 305-312. 
Table 1: Frequencies of unionization categories by academic year: numbers of schools and tested students

\begin{tabular}{|c|c|c|c|c|c|c|c|c|c|c|c|}
\hline \multicolumn{6}{|c|}{ Panel A: Numbers of charter schools. } & \multicolumn{6}{|c|}{ Panel B. Numbers of tested students. } \\
\hline & 1 & 2 & 3 & 4 & 5 & & 1 & 2 & 3 & 4 & 5 \\
\hline \multicolumn{6}{|c|}{ Switchers } & \multicolumn{6}{|c|}{ Switchers } \\
\hline & $\begin{array}{l}\text { Always } \\
\text { Unionized }\end{array}$ & $\begin{array}{l}\text { Now- } \\
\text { Union }\end{array}$ & $\begin{array}{l}\text { Not-Yet } \\
\text { Union }\end{array}$ & $\begin{array}{c}\text { Never } \\
\text { Unionized }\end{array}$ & Total & & $\begin{array}{c}\text { Always } \\
\text { Unionized }\end{array}$ & $\begin{array}{l}\text { Now- } \\
\text { Union }\end{array}$ & $\begin{array}{c}\text { Not-Yet } \\
\text { Union }\end{array}$ & $\begin{array}{c}\text { Never } \\
\text { Unionized }\end{array}$ & Total \\
\hline 2003 & 47 & 0 & 26 & 257 & 330 & 2003 & 16,829 & 0 & 14,260 & 67,838 & 98,927 \\
\hline 2004 & 56 & 2 & 30 & 331 & 419 & 2004 & 19,485 & 978 & 18,630 & 85,334 & 124,427 \\
\hline 2005 & 66 & 6 & 29 & 372 & 473 & 2005 & 21,635 & 6,021 & 14,249 & 95,627 & 137,532 \\
\hline 2006 & 71 & 10 & 27 & 431 & 539 & 2006 & 23,468 & 8,728 & 13,445 & 111,788 & 157,429 \\
\hline 2007 & 76 & 15 & 24 & 475 & 590 & 2007 & 26,177 & 11,246 & 13,079 & 128,460 & 178,962 \\
\hline 2008 & 81 & 21 & 20 & 522 & 644 & 2008 & 28,272 & 16,353 & 8,900 & 142,716 & 196,241 \\
\hline 2009 & 88 & 28 & 14 & 573 & 703 & 2009 & 32,542 & 20,824 & 4,586 & 163,479 & 221,431 \\
\hline 2010 & 93 & 33 & 6 & 639 & 771 & 2010 & 36,553 & 22,713 & 2,756 & 187,054 & 249,076 \\
\hline 2011 & 92 & 36 & 3 & 730 & 861 & 2011 & 38,287 & 21,759 & 2,109 & 218,066 & 280,221 \\
\hline 2012 & 92 & 38 & 0 & 805 & 935 & 2012 & 39,076 & 25,538 & 0 & 250,534 & 315,148 \\
\hline \multirow{2}{*}{$\begin{array}{l}\text { Unique } \\
\text { schools }\end{array}$} & \multirow[t]{2}{*}{99} & \multirow[t]{2}{*}{42} & \multirow{2}{*}{\multicolumn{2}{|c|}{985}} & \multirow{2}{*}{1,126} & Total & 282,324 & 226,174 & & $1,450,896 \quad 1$, & $1,959,394$ \\
\hline & & & & & & \multicolumn{6}{|c|}{ al describes the number of student-years in test data. } \\
\hline
\end{tabular}

Source: Author's calculations from California Department of Education data. Significance: *0.10 **0.05 ***0.01. 
Table 2: Summary statistics for all charters and sub-samples

\begin{tabular}{|c|c|c|c|c|}
\hline & $\begin{array}{c}1 \\
\text { All } \\
\text { Charters } \\
\text { mean/sd }\end{array}$ & $\begin{array}{c}2 \\
\text { Switchers } \\
\text { mean/sd }\end{array}$ & $\begin{array}{c}3 \\
\text { Never } \\
\text { Union } \\
\text { mean/sd }\end{array}$ & $\begin{array}{c}4 \\
\text { Always } \\
\text { Union } \\
\text { mean/sd }\end{array}$ \\
\hline Mean achievement z-score & $\begin{array}{c}-0.070 \\
(1.043)\end{array}$ & $\begin{array}{c}0.046 \\
(0.972)\end{array}$ & $\begin{array}{c}-0.120 \\
(1.032)\end{array}$ & $\begin{array}{c}0.094 \\
(1.120)\end{array}$ \\
\hline \multicolumn{5}{|l|}{ School demographics } \\
\hline \% Hispanic & $\begin{array}{c}41.887 \\
(29.439)\end{array}$ & $\begin{array}{c}46.681 \\
(30.851)\end{array}$ & $\begin{array}{c}39.829 \\
(28.447)\end{array}$ & $\begin{array}{c}48.882 \\
(31.779)\end{array}$ \\
\hline$\%$ White & $\begin{array}{c}36.308 \\
(28.610)\end{array}$ & $\begin{array}{c}33.017 \\
(26.382)\end{array}$ & $\begin{array}{c}37.303 \\
(28.949)\end{array}$ & $\begin{array}{c}33.648 \\
(28.094)\end{array}$ \\
\hline \% African American & $\begin{array}{c}10.740 \\
(16.217)\end{array}$ & $\begin{array}{c}9.358 \\
(10.399)\end{array}$ & $\begin{array}{c}11.486 \\
(17.890)\end{array}$ & $\begin{array}{c}7.936 \\
(8.552)\end{array}$ \\
\hline \% Asian/Pacific Islander & $\begin{array}{c}4.283 \\
(5.989)\end{array}$ & $\begin{array}{c}4.737 \\
(6.345)\end{array}$ & $\begin{array}{c}4.060 \\
(5.905)\end{array}$ & $\begin{array}{c}5.086 \\
(6.053)\end{array}$ \\
\hline \% American Indian & $\begin{array}{c}1.020 \\
(2.331)\end{array}$ & $\begin{array}{c}0.905 \\
(2.165)\end{array}$ & $\begin{array}{c}1.104 \\
(2.254)\end{array}$ & $\begin{array}{c}0.678 \\
(2.766)\end{array}$ \\
\hline \% American Filipino & $\begin{array}{c}1.662 \\
(2.815)\end{array}$ & $\begin{array}{c}1.816 \\
(2.471)\end{array}$ & $\begin{array}{c}1.740 \\
(3.028)\end{array}$ & $\begin{array}{c}1.147 \\
(1.596)\end{array}$ \\
\hline$\%$ FRL & $\begin{array}{c}46.772 \\
(31.921)\end{array}$ & $\begin{array}{c}49.297 \\
(31.572)\end{array}$ & $\begin{array}{c}46.151 \\
(31.204)\end{array}$ & $\begin{array}{c}48.079 \\
(35.490)\end{array}$ \\
\hline \% English Learners & $\begin{array}{c}16.559 \\
(20.977)\end{array}$ & $\begin{array}{c}20.496 \\
(25.836)\end{array}$ & $\begin{array}{c}14.922 \\
(19.827)\end{array}$ & $\begin{array}{c}22.034 \\
(21.363)\end{array}$ \\
\hline \% Not high school grad & $\begin{array}{c}17.195 \\
(18.487)\end{array}$ & $\begin{array}{c}20.095 \\
(20.561)\end{array}$ & $\begin{array}{c}15.530 \\
(17.189)\end{array}$ & $\begin{array}{c}23.566 \\
(21.392)\end{array}$ \\
\hline \% Some college & $\begin{array}{c}24.936 \\
(11.195)\end{array}$ & $\begin{array}{c}24.676 \\
(11.738)\end{array}$ & $\begin{array}{c}26.072 \\
(11.004)\end{array}$ & $\begin{array}{l}19.310 \\
(9.975)\end{array}$ \\
\hline \% College grad & $\begin{array}{c}21.896 \\
(12.918)\end{array}$ & $\begin{array}{c}20.709 \\
(12.784)\end{array}$ & $\begin{array}{c}22.340 \\
(12.766)\end{array}$ & $\begin{array}{c}20.506 \\
(13.617)\end{array}$ \\
\hline \% Grad school & $\begin{array}{c}13.660 \\
(12.825)\end{array}$ & $\begin{array}{c}12.575 \\
(11.076)\end{array}$ & $\begin{array}{c}13.262 \\
(12.053)\end{array}$ & $\begin{array}{c}16.501 \\
(16.852)\end{array}$ \\
\hline \% Education observed & $\begin{array}{c}83.309 \\
(20.236)\end{array}$ & $\begin{array}{c}84.174 \\
(17.145)\end{array}$ & $\begin{array}{c}82.902 \\
(21.248)\end{array}$ & $\begin{array}{c}84.755 \\
(16.631)\end{array}$ \\
\hline Charter operation variables & & & & \\
\hline Charter operation: Year 1-5 & $\begin{array}{c}0.424 \\
(0.494)\end{array}$ & $\begin{array}{c}0.218 \\
(0.413)\end{array}$ & $\begin{array}{c}0.482 \\
(0.500)\end{array}$ & $\begin{array}{c}0.285 \\
(0.451)\end{array}$ \\
\hline Charter operation: Year 6-10 & $\begin{array}{c}0.338 \\
(0.473)\end{array}$ & $\begin{array}{c}0.318 \\
(0.466)\end{array}$ & $\begin{array}{c}0.347 \\
(0.476)\end{array}$ & $\begin{array}{c}0.308 \\
(0.462)\end{array}$ \\
\hline Charter operation: Year 11+ & $\begin{array}{c}0.238 \\
(0.426)\end{array}$ & $\begin{array}{c}0.464 \\
(0.499)\end{array}$ & $\begin{array}{c}0.171 \\
(0.376)\end{array}$ & $\begin{array}{c}0.407 \\
(0.491)\end{array}$ \\
\hline School closes & $\begin{array}{c}0.064 \\
(0.245) \\
\end{array}$ & $\begin{array}{c}0.040 \\
(0.195) \\
\end{array}$ & $\begin{array}{c}0.079 \\
(0.269) \\
\end{array}$ & $\begin{array}{c}0.008 \\
(0.091) \\
\end{array}$ \\
\hline Student-gr-sub-years & $3,598,907$ & 399,431 & $2,673,869$ & 525,607 \\
\hline
\end{tabular}


Table 3: Effect of unionization on average achievement

\begin{tabular}{|c|c|c|c|c|c|c|}
\hline & 1 & 2 & 3 & 4 & 5 & 6 \\
\hline \multirow[t]{2}{*}{ Post-unionization } & $0.258 * *$ & $0.285^{* *}$ & $0.135 * *$ & 0.004 & 0.017 & 0.054 \\
\hline & $(0.131)$ & $(0.130)$ & $(0.061)$ & $(0.038)$ & $(0.037)$ & $(0.042)$ \\
\hline \multirow[t]{2}{*}{$2+$ yrs pre-unionization } & & & & & & 0.059 \\
\hline & & & & & & $(0.049)$ \\
\hline \multicolumn{7}{|l|}{ Charter age } \\
\hline \multirow[t]{2}{*}{ Year 6-10 } & & & $0.083 * *$ & 0.026 & 0.025 & 0.024 \\
\hline & & & $(0.036)$ & $(0.021)$ & $(0.021)$ & $(0.021)$ \\
\hline \multirow[t]{2}{*}{ Year 11+ } & & & 0.087 & -0.010 & -0.001 & -0.002 \\
\hline & & & $(0.063)$ & $(0.032)$ & $(0.031)$ & $(0.031)$ \\
\hline \multicolumn{7}{|l|}{ Demographics (\%) } \\
\hline \multirow[t]{2}{*}{ English Learners } & & & $-0.004 *$ & $-0.006 * * *$ & $-0.006 * * *$ & $-0.006 * * *$ \\
\hline & & & $(0.002)$ & $(0.001)$ & $(0.001)$ & $(0.001)$ \\
\hline \multirow[t]{2}{*}{ African American } & & & -0.002 & $-0.006 * * *$ & $-0.006 * * *$ & $-0.006 * * *$ \\
\hline & & & $(0.002)$ & $(0.002)$ & $(0.002)$ & $(0.002)$ \\
\hline \multirow[t]{2}{*}{ Asian } & & & $0.043^{* * *}$ & 0.004 & 0.004 & 0.004 \\
\hline & & & $(0.006)$ & $(0.004)$ & $(0.004)$ & $(0.004)$ \\
\hline \multirow[t]{2}{*}{ American Indian } & & & $-0.019 *$ & $-0.009 * *$ & $-0.009 * *$ & $-0.009 * *$ \\
\hline & & & $(0.010)$ & $(0.004)$ & $(0.004)$ & $(0.004)$ \\
\hline \multirow[t]{2}{*}{ Filipino } & & & 0.006 & 0.013 & 0.011 & 0.011 \\
\hline & & & $(0.007)$ & $(0.008)$ & $(0.008)$ & $(0.008)$ \\
\hline \multirow{2}{*}{ Hispanic/Latino } & & & $0.008 * * *$ & $-0.004 * *$ & $-0.004 * * *$ & $-0.004 * * *$ \\
\hline & & & $(0.002)$ & $(0.002)$ & $(0.002)$ & $(0.002)$ \\
\hline \multirow[t]{2}{*}{ Subsid. lunch eligible } & & & -0.001 & -0.000 & -0.000 & -0.000 \\
\hline & & & $(0.001)$ & $(0.000)$ & $(0.000)$ & $(0.000)$ \\
\hline \multirow[t]{2}{*}{ Parent Ed: Not HS grads } & & & $-0.005 * *$ & -0.000 & -0.000 & -0.000 \\
\hline & & & $(0.003)$ & $(0.001)$ & $(0.001)$ & $(0.001)$ \\
\hline \multirow[t]{2}{*}{ Parent Ed: Some college } & & & 0.003 & -0.000 & -0.000 & -0.000 \\
\hline & & & $(0.003)$ & $(0.001)$ & $(0.001)$ & $(0.001)$ \\
\hline \multirow[t]{2}{*}{ Parent Ed: College grad } & & & $0.017 * * *$ & $0.002 *$ & $0.002 * *$ & $0.002 * *$ \\
\hline & & & $(0.003)$ & $(0.001)$ & $(0.001)$ & $(0.001)$ \\
\hline \multirow[t]{2}{*}{ Parent Ed: Grad school } & & & $0.025 * * *$ & $0.002 * *$ & $0.002 *$ & $0.002 *$ \\
\hline & & & $(0.003)$ & $(0.001)$ & $(0.001)$ & $(0.001)$ \\
\hline Year effects & & $\mathrm{Y}$ & $\mathrm{Y}$ & $\mathrm{Y}$ & $\mathrm{Y}$ & $\mathrm{Y}$ \\
\hline Subject-Grade FE & & Y & $\mathrm{Y}$ & $\mathrm{Y}$ & & \\
\hline Controls & & & $\mathrm{Y}$ & $\mathrm{Y}$ & $\mathrm{Y}$ & $\mathrm{Y}$ \\
\hline School FE & & & & $\mathrm{Y}$ & & \\
\hline School-Gr-Subject FE & & & & & Y & Y \\
\hline Schools & 1,126 & 1,126 & 1,126 & 1,126 & 1,126 & 1,126 \\
\hline School-grade-subjs & 10,745 & 10,745 & 10,745 & 10,745 & 10,745 & 10,745 \\
\hline Student-gr-sub-years & $3,598,907$ & $3,598,907$ & $3,598,907$ & $3,598,907$ & $3,598,907$ & $3,598,907$ \\
\hline
\end{tabular}


Table 4: Effects of unionization on average achievement, by sample

Effects of or selection into unionization on scores pooled across subjects, by sample

\begin{tabular}{|c|c|c|c|c|c|}
\hline & $\begin{array}{c}1 \\
\text { All Charters }\end{array}$ & $\begin{array}{c}2 \\
\text { Switchers+ } \\
\text { Never-Union } \\
\text { b/se }\end{array}$ & $\begin{array}{c}3 \\
\text { Switchers only }\end{array}$ & $\begin{array}{c}4 \\
\text { All charters } \\
\text { and TPS } \\
\text { b/se }\end{array}$ & $\begin{array}{c}5 \\
\text { All Charters, } \\
\text { Excl. } \\
\text { Conversion } \\
\text { b/se }\end{array}$ \\
\hline Post-unionization & $\begin{array}{c}0.017 \\
(0.037)\end{array}$ & $\begin{array}{c}0.018 \\
(0.039)\end{array}$ & $\begin{array}{c}-0.089 * * \\
(0.043)\end{array}$ & $\begin{array}{c}0.032 \\
(0.034)\end{array}$ & $\begin{array}{c}0.005 \\
(0.056)\end{array}$ \\
\hline Year effects & $\mathrm{Y}$ & $\mathrm{Y}$ & $\mathrm{Y}$ & $\mathrm{Y}$ & $\mathrm{Y}$ \\
\hline Controls & Y & $\mathrm{Y}$ & $\mathrm{Y}$ & $\mathrm{Y}$ & $\mathrm{Y}$ \\
\hline School-Grade-Subject FE & $\mathrm{Y}$ & $\mathrm{Y}$ & $\mathrm{Y}$ & $\mathrm{Y}$ & $\mathrm{Y}$ \\
\hline Schools & 1,126 & 1,028 & 42 & 10,711 & 970 \\
\hline School-grade-subjs & 10,745 & 9,840 & 479 & 92,139 & 9,196 \\
\hline Student-gr-sub-years & $3,598,907$ & $3,073,300$ & 399,431 & $88,600,438$ & $2,594,397$ \\
\hline
\end{tabular}

Source: Author's calculations from California Department of Education data. Significance: *0.10**0.05***0.01. Controls include ethnic composition, percent English Learners, parental education, percent subsidized lunch eligible and charter age categories. Missing variable dummies (not shown) are included for schools missing demographic information. Weighted by the total number of students tested in each school-grade-subject cell. 
Table 5: Effects of unionization on percentage attaining various proficiency levels

\begin{tabular}{lccc}
\hline & $\begin{array}{c}1 \\
\text { \% Advanced }\end{array}$ & $\begin{array}{c}2 \\
\text { \% Proficient } \\
\text { or better } \\
\text { b/se }\end{array}$ & $\begin{array}{c}\text { \% Basic or } \\
\text { better } \\
\text { b/se }\end{array}$ \\
\hline Post-unionization & b/se & 0.241 & 0.692 \\
& -0.407 & $(0.870)$ & $(0.921)$ \\
\hline Year effects & $(0.664)$ & $\mathrm{Y}$ & $\mathrm{Y}$ \\
Controls & $\mathrm{Y}$ & $\mathrm{Y}$ & $\mathrm{Y}$ \\
School-Grade-Subject FE & $\mathrm{Y}$ & $\mathrm{Y}$ & $\mathrm{Y}$ \\
Schools & $\mathrm{Y}$ & 1,126 & 1,126 \\
School-grade-subjs & 1,126 & 10,745 & 10,745 \\
Student-gr-sub-years & 10,745 & $3,598,907$ & $3,598,907$ \\
\hline
\end{tabular}

Source: Author's calculations from California Department of Education data. Significance: *0.10**0.05 ***0.01. Sample includes all charter schools. Controls include ethnic composition, percent English Learners, parental education, percent subsidized lunch eligible and charter age categories. Missing variable dummies (not shown) are included for schools missing demographic information. Weighted by the total number of students tested in each school-grade-subject cell. 
Table 6: Effects of unionization on average achievement by subject

\begin{tabular}{|c|c|c|c|}
\hline & \multicolumn{2}{|c|}{ Panel A: CSTs } & Panel B: API \\
\hline & $\begin{array}{l}\text { ELA } \\
\mathrm{b} / \mathrm{se}\end{array}$ & Math & API \\
\hline Post-unionization & $\begin{array}{c}0.007 \\
(0.030) \\
\end{array}$ & $\begin{array}{c}0.108 \\
(0.088)\end{array}$ & $\begin{array}{c}0.041 \\
(0.047)\end{array}$ \\
\hline Year effects & $\mathrm{Y}$ & $\mathrm{Y}$ & $\mathrm{Y}$ \\
\hline Controls & $\mathrm{Y}$ & $\mathrm{Y}$ & $\mathrm{Y}$ \\
\hline School-Grade FE & $\mathrm{Y}$ & $\mathrm{Y}$ & \\
\hline School FE & & & $\mathrm{Y}$ \\
\hline Schools & 1,125 & 767 & 1,110 \\
\hline School-grades & 5,409 & 2,779 & \\
\hline Student-gr-years & $1,908,223$ & 800,645 & \\
\hline
\end{tabular}

Source: Author's calculations from California Department of Education data. Significance: $* 0.10 * * 0.05 * * * 0.01$. Coefficient (within-school correlation robust SE). Sample includes all charter schools. Controls include ethnic composition, percent English Learners, parental education, percent subsidized lunch eligible and charter age categories. Missing variable dummies (not shown) are included for schools missing demographic information. Panel A weighted by studentgrade-year counts. Panel B weighted by student-year counts. CST: California Standards Test. API: Academic Performance Index 
Figure 1. Trend in average achievement by static unionization category

\section{Trend in achievement by unionization category} Sample: All Charters

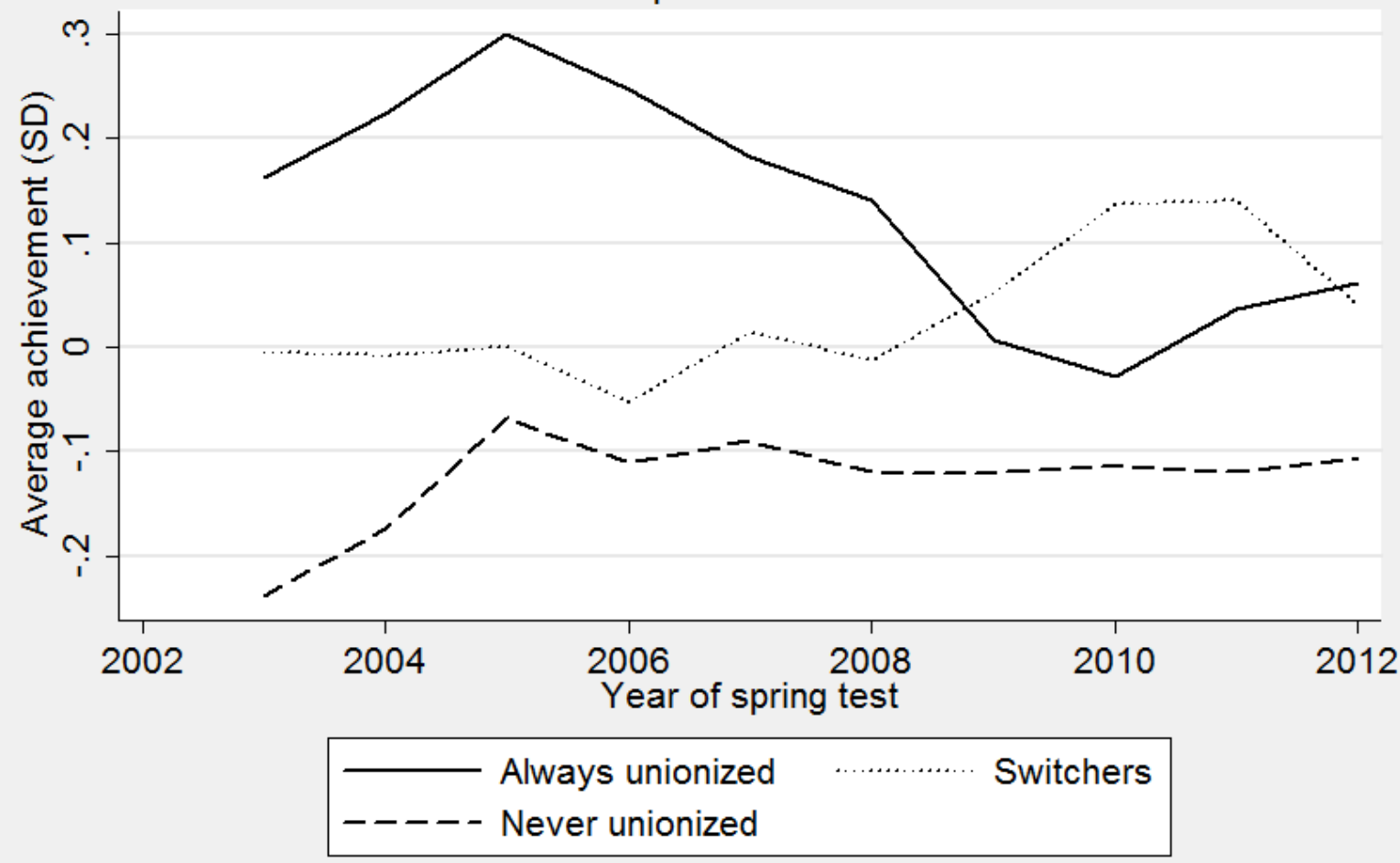

Note: Includes all subjects. Scores are standardized to mean zero and standard deviation one in the set of all California Public School students, charter and traditional schools within each subject-grade-year. To compute subsample means, we weight each school-grade-subject-year observation by the number of students tested. 
Figure 2. Effects of unionization on achievement z-score by elapse to unionization

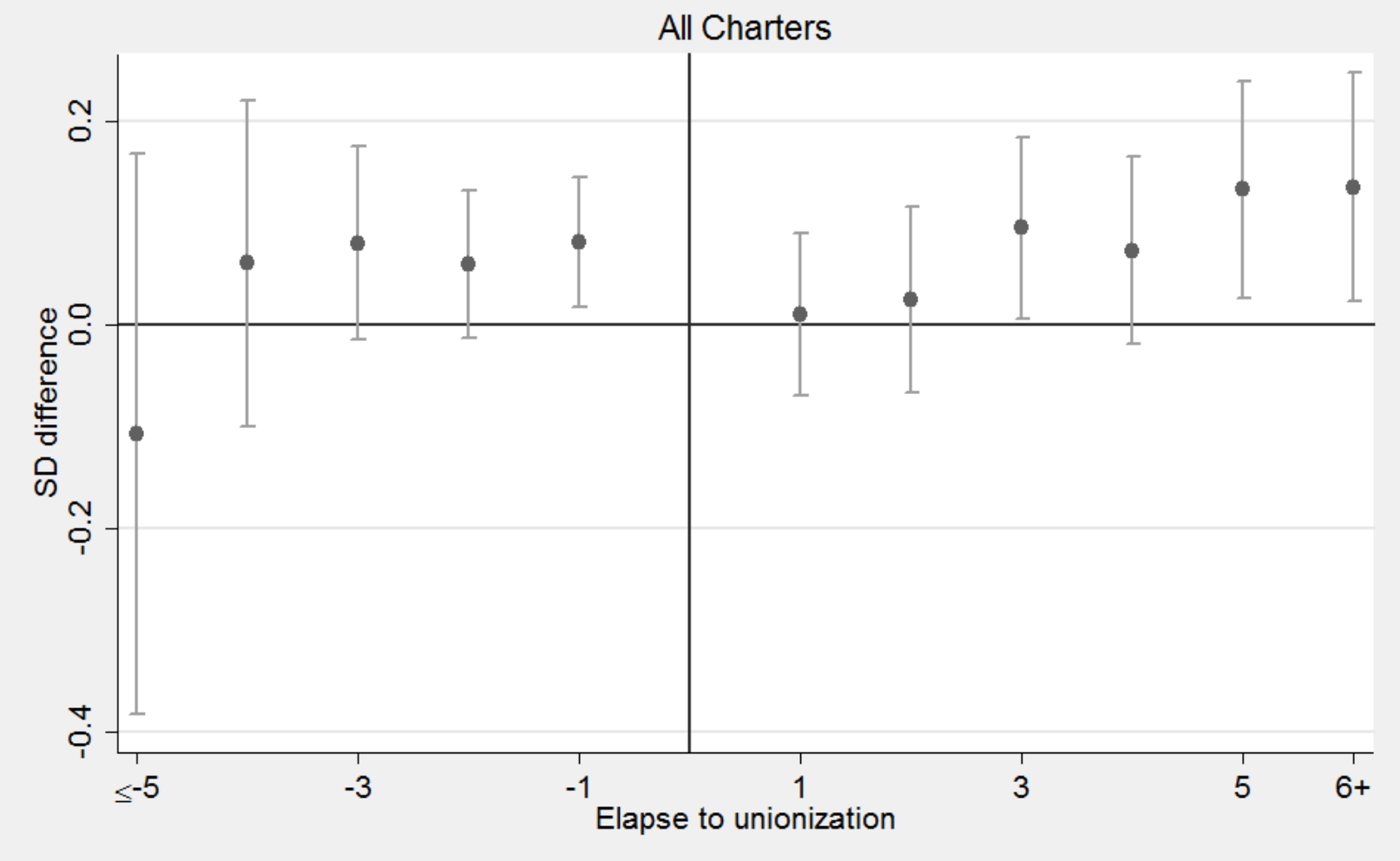

Note: Omitted year (Year 0) is the year prior to the year unionization takes effect 


\section{Appendix A}

Table A.1: Tests and tested grades

\begin{tabular}{|c|c|c|}
\hline Test & Grades & Notes \\
\hline English Language Arts & $2-11$ & \\
\hline Math & $2-6$ & $\begin{array}{l}7^{\text {th }} \text { graders take either the general math } \\
\text { CST or an Algebra I Test. We exclude } 7^{\text {th }} \\
\text { graders in our analysis }\end{array}$ \\
\hline Science & $5,8,10$ & $\begin{array}{l}8^{\text {th }} \text { and } 10^{\text {th }} \text { grade tests first administered } \\
\text { in } 2005-06\end{array}$ \\
\hline History-Social Science & 8 & \\
\hline US History & 11 & \\
\hline
\end{tabular}


Table A.2 Differences in achievement (z-scores) by years to unionization

\begin{tabular}{|c|c|c|c|c|}
\hline & All Charters & $\begin{array}{c}\text { Switcher+ } \\
\text { Never Union } \\
\text { b/se }\end{array}$ & $\begin{array}{c}\text { Switchers+ } \\
\text { Always Union } \\
\text { b/se }\end{array}$ & $\begin{array}{l}\text { All Charters, } \\
\text { Excl. } \\
\text { Conversions } \\
\text { b/se }\end{array}$ \\
\hline Elapse to certif. year $<=-5$ & $\begin{array}{l}-0.107 \\
(0.140)\end{array}$ & $\begin{array}{l}-0.105 \\
(0.138)\end{array}$ & $\begin{array}{l}-0.108 \\
(0.139)\end{array}$ & $\begin{array}{c}0.050 \\
(0.147)\end{array}$ \\
\hline Elapse to cert. year $=-4$ & $\begin{array}{c}0.061 \\
(0.082)\end{array}$ & $\begin{array}{c}0.057 \\
(0.083)\end{array}$ & $\begin{array}{c}0.066 \\
(0.079)\end{array}$ & $\begin{array}{l}0.168^{* * *} \\
(0.067)\end{array}$ \\
\hline Elapse to cert. year $=-3$ & $\begin{array}{l}0.081^{*} \\
(0.048)\end{array}$ & $\begin{array}{c}0.076 \\
(0.048)\end{array}$ & $\begin{array}{l}0.088^{*} \\
(0.049)\end{array}$ & $\begin{array}{l}0.135 * * \\
(0.055)\end{array}$ \\
\hline Elapse to cert. year $=-2$ & $\begin{array}{c}0.060 \\
(0.037)\end{array}$ & $\begin{array}{c}0.053 \\
(0.038)\end{array}$ & $\begin{array}{l}0.073^{*} \\
(0.037)\end{array}$ & $\begin{array}{c}0.099 * * \\
(0.048)\end{array}$ \\
\hline Elapse to cert. year $=-1$ & $\begin{array}{l}0.081^{* *} \\
(0.032)\end{array}$ & $\begin{array}{c}0.075^{* *} \\
(0.034)\end{array}$ & $\begin{array}{c}0.085 * * * \\
(0.030)\end{array}$ & $\begin{array}{c}0.071^{* *} \\
(0.035)\end{array}$ \\
\hline Elapse to cert. year $=1$ & $\begin{array}{c}0.010 \\
(0.041)\end{array}$ & $\begin{array}{l}-0.008 \\
(0.043)\end{array}$ & $\begin{array}{c}0.001 \\
(0.039)\end{array}$ & $\begin{array}{c}0.019 \\
(0.062)\end{array}$ \\
\hline Elapse to cert. year $=2$ & $\begin{array}{c}0.025 \\
(0.047)\end{array}$ & $\begin{array}{c}0.010 \\
(0.052)\end{array}$ & $\begin{array}{c}0.011 \\
(0.043)\end{array}$ & $\begin{array}{c}0.061 \\
(0.061)\end{array}$ \\
\hline Elapse to cert. year $=3$ & $\begin{array}{c}0.095^{* *} \\
(0.046)\end{array}$ & $\begin{array}{c}0.104^{* * *} \\
(0.051)\end{array}$ & $\begin{array}{c}0.073 \\
(0.045)\end{array}$ & $\begin{array}{l}0.124 * \\
(0.070)\end{array}$ \\
\hline Elapse to cert. year $=4$ & $\begin{array}{c}0.073 \\
(0.047)\end{array}$ & $\begin{array}{c}0.064 \\
(0.052)\end{array}$ & $\begin{array}{c}0.045 \\
(0.051)\end{array}$ & $\begin{array}{c}0.118 \\
(0.076)\end{array}$ \\
\hline Elapse to cert. year $=5$ & $\begin{array}{c}0.133^{* *} \\
(0.054)\end{array}$ & $\begin{array}{c}0.168 * * * \\
(0.065)\end{array}$ & $\begin{array}{c}0.091 \\
(0.063)\end{array}$ & $\begin{array}{c}0.153 \\
(0.095)\end{array}$ \\
\hline Elapse to cert. year $>=6$ & $\begin{array}{l}0.136^{* *} \\
(0.057)\end{array}$ & $\begin{array}{l}0.168^{* *} \\
(0.065)\end{array}$ & $\begin{array}{c}0.057 \\
(0.064)\end{array}$ & $\begin{array}{l}0.156^{*} \\
(0.089)\end{array}$ \\
\hline Charter operation: Year 6-10 & $\begin{array}{c}0.025 \\
(0.021)\end{array}$ & $\begin{array}{l}0.037^{*} \\
(0.021)\end{array}$ & $\begin{array}{c}0.059 \\
(0.043)\end{array}$ & $\begin{array}{c}0.030 \\
(0.022)\end{array}$ \\
\hline Charter operation: Year 11+ & $\begin{array}{l}-0.002 \\
(0.031)\end{array}$ & $\begin{array}{c}0.011 \\
(0.033)\end{array}$ & $\begin{array}{c}0.033 \\
(0.060)\end{array}$ & $\begin{array}{c}0.007 \\
(0.036)\end{array}$ \\
\hline Schools & 1,126 & 1,028 & 141 & 970 \\
\hline School-grade-subjs & 10,744 & 9,841 & 1,383 & 9,197 \\
\hline Student-gr-sub-years & $3,598,907$ & $3,073,300$ & 925,038 & 2,594,397 \\
\hline
\end{tabular}

Source: Author's calculations from California Department of Education data. Significance: ${ }^{*} 0.10 * * 0.05 * * * 0.01$. Models also include student and parents demographics, year-subject indicators, and school-grade-subject indicators. Weighted by the total number of students tested in each school-grade-subject cell. Omitted year is the first lead year (therefore, Elapse to cert. year=-1 is the second lead year, etc.). 
Table A.3. Associations between unionization and enrollment and demographic composition

\begin{tabular}{ccc}
\hline & \multicolumn{2}{c}{ Predictors: unionization } \\
Post- & $\begin{array}{c}\text { 2+ years pre- } \\
\text { unionization } \\
\text { untcome } \\
\text { b/se }\end{array}$ & $\begin{array}{c}\text { b/se } \\
\text { Log Enrollment }\end{array}$ \\
& -0.030 & 0.032 \\
& $(0.059)$ & $(0.059)$ \\
Demographics & & \\
\%Hispanic & 1.044 & 0.714 \\
& $(1.180)$ & $(1.084)$ \\
\% Af. Am. & 0.515 & 1.237 \\
& $(0.745)$ & $(1.085)$ \\
\% Asian & 0.215 & -0.151 \\
& $(0.194)$ & $(0.180)$ \\
\%Native & 0.222 & -0.263 \\
& $(0.452)$ & $(0.349)$ \\
\%Filipino & 0.226 & 0.485 \\
& $(0.240)$ & $(0.335)$ \\
\%FRL & 0.998 & 0.711 \\
& $(2.777)$ & $(5.030)$ \\
\%ELL & -0.754 & 0.591 \\
& $(0.990)$ & $(1.540)$
\end{tabular}

Parental education

$\begin{array}{ccc}\text { \%Not HS Grad } & 0.873 & 0.448 \\ & (0.613) & (0.684) \\ \text { \%Some Coll. plus } & -1.902 * & 0.483 \\ & (1.136) & (1.222) \\ \text { \%Coll Grad plus } & -0.026 & 0.001 \\ & (1.003) & (1.612)\end{array}$

Source: Author's calculations from California Department of Education data. Significance: *0.10**0.05***0.01. Sample includes all charter schools. Missing variable dummies (not shown) are included for schools missing demographic information. All analyses except log enrollment weighted by tested student counts. All models control for year dummies, charter school age, and school fixed effects. Log enrollment models are estimated on 1,126 schools over 6,625 school-years. Other models estimated for 1,120 schools and represent 1,903,569 student-years. 
Table A.4. Hazard model for school closure by unionization status, hazard ratios

\begin{tabular}{|c|c|c|c|}
\hline & \multicolumn{3}{|c|}{ Sample } \\
\hline & & & All Charters \\
\hline & & Switcher+ & Excl. \\
\hline & $\begin{array}{c}\text { All Charters } \\
\text { b/se }\end{array}$ & $\begin{array}{c}\text { Never-Union } \\
\text { b/se }\end{array}$ & $\begin{array}{c}\text { Conversions } \\
\text { b/se }\end{array}$ \\
\hline \multirow[t]{2}{*}{ Post-unionization } & $0.355 * * *$ & 1.117 & $0.363 * * *$ \\
\hline & $(0.121)$ & $(0.595)$ & $(0.140)$ \\
\hline \multirow{2}{*}{$\begin{array}{l}\text { Pct. eligible for subsidized } \\
\text { lunch }\end{array}$} & 1.001 & 1.000 & 1.000 \\
\hline & $(0.003)$ & $(0.004)$ & $(0.004)$ \\
\hline \multirow[t]{2}{*}{ Pct. English Learners } & $0.988 * *$ & $0.989 * *$ & $0.987 * *$ \\
\hline & $(0.005)$ & $(0.005)$ & $(0.006)$ \\
\hline \multirow[t]{2}{*}{ Pct. Parent Ed: Not HS grads } & 1.005 & 1.002 & 1.005 \\
\hline & $(0.007)$ & $(0.007)$ & $(0.008)$ \\
\hline \multirow[t]{2}{*}{ Pct. Parent Ed: Some college } & 0.992 & 0.991 & 0.994 \\
\hline & $(0.007)$ & $(0.007)$ & $(0.007)$ \\
\hline \multirow[t]{2}{*}{ Pct. Parent Ed: College grad } & 1.004 & 1.004 & 1.005 \\
\hline & $(0.005)$ & $(0.005)$ & $(0.005)$ \\
\hline \multirow[t]{2}{*}{ Pct. Parent Ed: Grad. school } & $0.979 * *$ & $0.980 * *$ & $0.981 * *$ \\
\hline & $(0.009)$ & $(0.009)$ & $(0.009)$ \\
\hline Year effects & $\mathrm{Y}$ & $\mathrm{Y}$ & $\mathrm{Y}$ \\
\hline Controls & $\mathrm{Y}$ & $\mathrm{Y}$ & $\mathrm{Y}$ \\
\hline Schools & 1,165 & 1,066 & 1,008 \\
\hline School-Years & 6,170 & 5,439 & 5,185 \\
\hline
\end{tabular}




\section{Notes}

${ }^{1}$ State laws governing teachers' unionization rights vary widely, as do states' teacher unionization rates, which range between 14 and 77 percent (Sojourner, 2013). In 2012, half of U.S. elementary and secondary teachers belonged to a union and half did not (Hirsch \& Macpherson, 2013).

${ }^{2}$ Increased management flexibility is one of the main rationales for the adoption of charter laws (Chubb \& Moe, 1990; Wells, 1998). Supporters of California's charter laws saw charter schools as a way, "to ease the restrictions of California's influential collective bargaining law” (Hart \& Burr, 1996). Though the example draws from California's experience, similar logic motivates charter policy elsewhere. Increasing public-school choice and competition are other important rationales.

${ }^{3}$ California Assembly Bill 631, which passed in 1999, explicitly extended the right to organize and collectively bargain to staff in charter schools. Moss (2010) provides an extensive discussion of collective bargaining in California charter schools including legal history, institutional detail, and interviews with school staff, but no analysis of effects on achievement.

${ }^{4}$ According to the National Alliance for Public Charter Schools (2011), only Wisconsin had more unionized charter schools than California, 171 versus 122. However, because Wisconsin state law binds charters to collective bargaining agreements automatically, there are no pre-unionization observations available there. In contrast, California law does not create automatic charter-school unionization, so both pre- and post-unionization data is available for many schools. All other states have far fewer unionized charter schools. Ohio has third-most with only 42, the vast majority bound by law.

${ }^{5}$ California's standardized tests are administered during March for most schools (California Department of Education, 2013), so schools with teacher bargaining units certified by PERB during March or after in year $t$ are assumed to be first unionized with respect to test scores measured in the spring of year $t+1$. Year $t$ is therefore the omitted year.

${ }^{6}$ We exclude Crescendo schools, due to a cheating scandal around (Blume, 2012).

${ }^{7}$ In an extreme and simplified form of their setting, where all schools unionize at once, there can be no correlation of unobserved school type with unionization timing because there is no variation in timing. The drawback is that the change in union status is confounded with any simultaneous changes in the environment. In contrast, we have variation in timing and we use year effects to control for environmental changes.

${ }^{8}$ Omitted fractions are non-ELL, non-Hispanic White, full-price lunch, less than high school, and parent education missing.

${ }^{9}$ A recent magazine article offered an example of this perception at a California charter school. Teachers felt, "the school's administration was beginning to shift slightly away from the entrepreneurial focus that they thought was essential to the school's mission and success. Teachers were also growing restless over a series of top-down decisions that were affecting their work in the classroom. As at-will employees, staff at [the school] weren't empowered to advocate for their students” (Walker, 2013).

${ }^{10}$ This may have been the story behind the events at one small charter school, "The union was established by the vote of only two teachers in favor of the union, one of whom requested the vote after being notified that her employment would not be renewed...” (Moss, 2010).

${ }^{11}$ Always-union (never-union) schools have post-unionization equal $1(0)$ always and $2+$ years preunionization equal $0(0)$ always.

${ }^{12}$ When school-year observations are weighted by student counts, results are similar though the estimated post-unionization coefficient in Switchers + Never-Union sample falls below 1 and remains insignificant.

${ }^{13}$ This is consistent with findings that teacher productivity falls with district size in California's traditional public school districts (Rose \& Sonstelie, 2010). They are all generally unionized but larger districts will tend to face less competition (Tiebout, 1956; Hoxby, 2000).

${ }^{14}$ Budd (2004) discusses this distinction in detail. 